\title{
Origination of extant heteroconch families: Ecological and environmental patterns in post-Paleozoic bivalve diversification
}

\author{
YASUO KONDO $^{1}$ AND SHIN-ICHI SANO ${ }^{2}$ \\ ${ }^{1}$ Department of Earth Science, Faculty of Science, Kochi University, Akebono-cho 2-5-1, Kochi, 780-8520, Japan (ykondo@cc.kochi-u.ac.jp) \\ ${ }^{2}$ Fukui Prefectural Dinosaur Museum, Terao 51-11, Muroko-cho, Katsuyama, Fukui, 911-8601, Japan
}

Received June 23, 2008; Revised manuscript accepted January 26, 2009

\begin{abstract}
In an attempt to understand the timing and structure of post-Paleozoic adaptive radiation of bivalves, temporal patterns of origination of extant heteroconch families were analyzed, based on the normalized number of originated families per $6 \mathrm{My}$ (NNFO). The mean value through the Mesozoic and Cenozoic is 1.34. The origination occurred temporally unevenly. Three intervals and two events which are characterized by higher rate of origination of families were recognized; Carnian to Hettangian, Mid-Cretaceous, and Paleocene/Eocene Origination Intervals, and Campanian and Lower Miocene Origination Events. Each origination interval or event appears to be characteristic of a salinity regime. Freshwater families originated only in the Late Triassic and Neogene. In contrast, nearly all the families that originated in the Late Cretaceous were marine. This appears to match the Wilson Cycle corresponding to continental aggregation and separation. The actual rather complex pattern of heteroconch family origination recognized in this study is probably a composite of such effects of the long-term pattern associated with the Wilson Cycle, change in nutrient level, predation pressure, and seawater chemistry.
\end{abstract}

Key words: Adaptive radiation, bivalve, Heteroconchia, origination, post-Paleozoic

\section{Introduction}

The post-Paleozoic evolutionary history of bivalves has been regarded as a typical example of adaptive radiation. Taxonomic and ecological aspects of the diversification were discussed by some authors (e.g., Stanley, 1968; Skelton et al., 1990). Skelton et al. (1990) used number of families and taxonomic and ecological composition in analyzing postPaleozoic adaptive divergence and the taxonomic radiation of bivalves. Composition, proportion and their temporal change were analyzed in the study, and more or less proportionate diversification was emphasized, except for the disproportionate increase of the siphonate group and the demise of mostly epifaunal Pteriomorphia.

In this study, we paid attention to the timing of origination of heteroconch families, rather than familial composition or proportion of the bivalve fauna at that time, because origination of families, as with other higher taxa such as superfamilies or orders, is considered to be the consequence of natural selection within the predominant environment at that time. Extant families are particularly important, because definite rather than inferred ecological information is available for them. Heteroconchia is a monophyletic bivalve group consisting of Heterodonta, Paleoheterodonta and
Anomalodesmata, corresponding to all the bivalves excluding Protobranchia and Pteriomorphia (Giribet and Wheeler, 2002). Post-Paleozoic Heteroconchia includes most of the features of evolutionary diversification shown by bivalves. The habitat of Heteroconchia ranges across the entire salinity regime from marine to freshwater, and a variety of aquatic environments from lacustrine, riverine, nearshore, and shelf to deep marine. Heteroconchia originated in early Paleozoic, but most of its diversification occurred after the end-Permian mass extinction.

Thus, the temporal pattern of origination of extant postPaleozoic heteroconch families was analyzed to understand the detailed timing and ecological structure of the adaptive radiation, on the basis of the ecological and environmental preferences of extant members of the family.

\section{Method of analysis}

Family was chosen as the basic unit of analysis in this study. In bivalves, superfamily has been employed in analyzing post-Paleozoic adaptive radiation (Stanley, 1968). Family is now, however, more accurate, being generally considered to be a practical taxonomic unit for evaluating the history of biodiversity (e.g., Sepkoski, 1981). Fortunately, a reasonably 

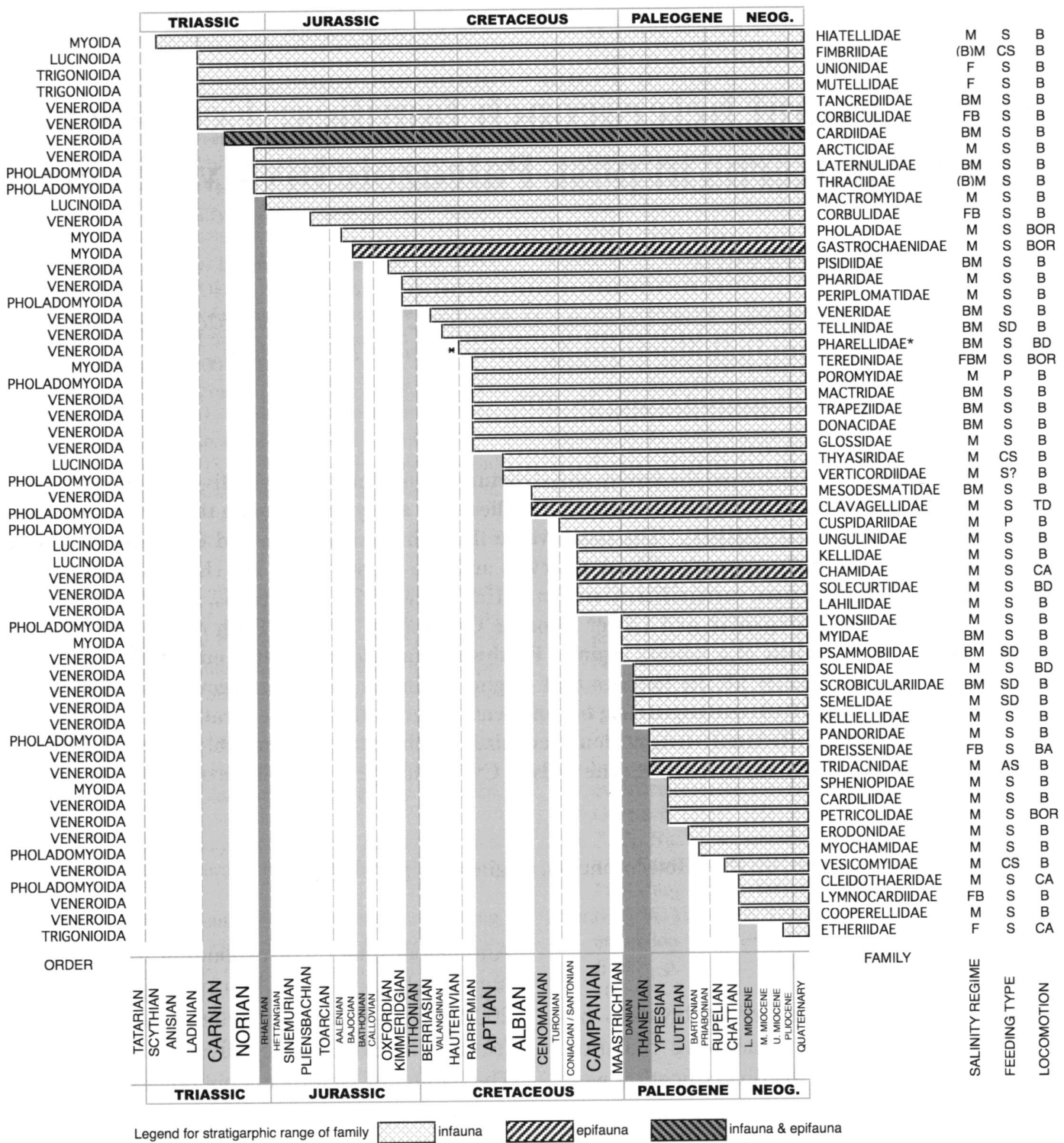

Legend for stratigarphic range of family

infauna

Figure 1. Stratigraphic range of extant heteroconch families, with common or predominant environmental and ecologic characteristics of extant species of the family. Thick shading shows that the NNFO value, or number of origination of extant heteroconch families normalized per 6 Ma, is more than twice the average, or 2.8. Similarly, weak shading represents values of 2.0-2.8. Abbreviations are as follows. Salinity regime, F: freshwater, B: brackish, M: marine. Feeding type, S; suspension feeder, P: predator, SD: siphonate deposit-feeder, AS: algal symbiotic feeder, CS: chemosynthetic feeder. *Data from Cretaceous in Japan (Yabe et al., 1926). Locomotion/attachment, B: burrower, BD: burrow dweller, BOR: borer, CA: cement-attached form, TD: tube dweller.

well documented database on the stratigraphic range of bivalve families is available (Skelton and Benton, 1993). We emended only one family on the basis of studies in Japan; the origination of Pharellidae is corrected as Barremian as in Yabe et al. (1926).

To analyze the temporal pattern of post-Paleozoic diversification of Heteroconchia, the families treated in this study were selected as follows. Out of 100 bivalve families present in the Mesozoic and Cenozoic, only extant families belong- ing to Heteroconchia (sensu Cox 1960) were treated; families belonging to Pteriomorphia and Protobranchia were excluded, because the adaptive radiation of post-Paleozoic bivalves was achieved mostly by Heteroconchia. Heteroconchia has been confirmed to be a monophyletic group (Giribet and Wheeler, 2002). Also, those families that originated in the Paleozoic, that is, Lucinidae, Astartidae Crassatellidae, Carditidae and Pholadomyidae, were excluded. In addition, a family without any fossil record, Gauconomi- 
dae, was excluded. Parasitic families, namely, Gaimardiidae, Erycinidae, and Neoleptonidae were excluded, to avoid overestimation of very small or microscopic bivalves in the ecosystems. Most of these belong to Lucinata and originated in the Paleogene. Thus, 57 families remained to be treated in this study.

Stages used in this study were identical to those defined by Harland et al. (1990), which were adopted by Skelton and Benton (1993). Ages of stage boundaries were cited from Gradstein et al. (2004).

For the 57 families stated above, the number of originated families were counted for each stage, and the normalized numbers of families originated in each stage per $6 \mathrm{My}$ (NNFO) were calculated, with the longest one $13 \mathrm{My}$ for Aptian and Campanian, and the shortest 2.3 My for Santonian. 6 My is the mean value of the duration of a stage in the Mesozoic and Cenozoic.

For ecological and environmental interpretation, salinity regime, feeding type, and mode of locomotion/attachment were compiled for each family, on the basis of common or predominant characteristics of extant species of the family. Salinity regime is divided into four categories: freshwater, freshwater/brackish, brackish/marine and marine, based on Skelton and Benton (1993) and Kondo et al. (2006). Feeding type is classified under suspension feeder, siphonate deposit feeder, carnivore and those fed by chemosynthesis and algal symbiosis. As to mode of locomotion and attachment, soft-bottom burrower, hard-bottom borer, burrow dweller and cement-attached form were represented. These ecological characteristics of families are based on Stanley (1968), Kondo (2001) and references therein.

In this study, we need to postulate that ecological preferences, such as feeding type, salinity regime and mode of locomotion/attachment of the family, have not changed from the emergence of the family onwards. In our experience, this assumption appears to be tenable, but should be examined in more detail. As for salinity regime, a systematic paleoecological study established the basis of reconstruction of paleosalinity (Fürsich, 1994), so such results (e.g., Kondo et al., 2006) were also cited where available in this study.

\section{Results}

Figure 1 illustrates the stratigraphic range of and ecological information for all the families analyzed in this study. The number of originated families, NNFO, and information on ecological composition (salinity regime, feeding types, mode of locomotion/attachment) is shown in Figure 2. The mean NNFO value through the Mesozoic and Cenozoic is 1.34. By far the highest values of NNFO are recorded for the Danian (4.7), Rhaetian (4.5) and Thanetian (4.1). Following these, stages or divisions with NNFO values larger that 2.0 are Carnian (2.6), Tithonian (2.3), Aptian (2.8), Ypre- sian (2.5), Lutetian (2.2) and Lower Miocene (2.5). These are considered to represent heteroconch family origination events. Among these, two types of events may be distinguished; Rhaetian and Danian/Thanetian events characterized by distinctly high NNFO values in a short time period, and Carnian, Aptian and Paleogene events with moderately high NNFO values for longer periods.

The first massive appearance of heteroconch families after the end-Permian extinction event, including Fimbriidae, Unionidae, Mutellidae, Tancrediidae and Corbiculidae, occurred in the Carnian. Only one family, Cardiidae, appeared in the subsequent Norian, but the Rhaetian saw the origination of three families, Arcticidae, Laternulidae and Thraciidae in spite of its short timespan. Crossing over the $\mathrm{T} / \mathrm{J}$ boundary, the Hettangian also shows a moderately high NNFO value, 1.9, although only one family, Mactromyidae, originated in this stage. Considering an extinct family not treated in the calculation, the Hettangian may be noteworthy because a brackish/freshwater family Neomiodontidae appeared in this stage. The period of high origination rates from Carnian to Hettangian is termed here the Carnian to Hettangian Origination Interval.

All the families originated in this interval are found in freshwater, freshwater/brackish or brackish/marine habitats, including Neomiodontidae; no stenohaline, pure-marine families originated. Members of the family Fimbriidae are now found in marine waters, but the earliest occurrence of the family from the Carnian Mine Group in western Japan was in a brackish facies (Tokuyama, 1960). All the families originated in this interval were soft-bottom suspension-feeders.

No or only one family originated in each stage from the Sinemurian to Barremian, except for the Tithonian, for which 2 were recorded. Thus, most of the Jurassic and Early Cretaceous was an interval of low rate of origination.

The Aptian recorded the highest number of families originated per stage (6), although the longest period of the stage 13.0 My makes the NNFO value smaller (2.8). The subsequent Albian and Cenomanian stages recorded average or moderately high rates of origination. This Aptian to Cenomanian origination interval (here termed the Mid-Cretaceous Origination Interval) is characterized by origination of both brackish and marine families. Nearshore inhabitants including Donacidae and Mesodesmatidae originated in this interval. Three brackish/marine families that originated immediately before this interval (Veneridae in the Valanginian, Tellinidae in the Hauterivian and Pharellidae in the Barremian) may be precursors of the Mid-Cretaceous Origination Interval.

Intercalated between the Mid-Cretaceous and Paleocene/Eocene Origination Intervals there occurred a shorter, but outstanding origination event in the Campanian (here termed the Campanian Origination Event). The number of originated families in this stage and the Carnian is 5, being 

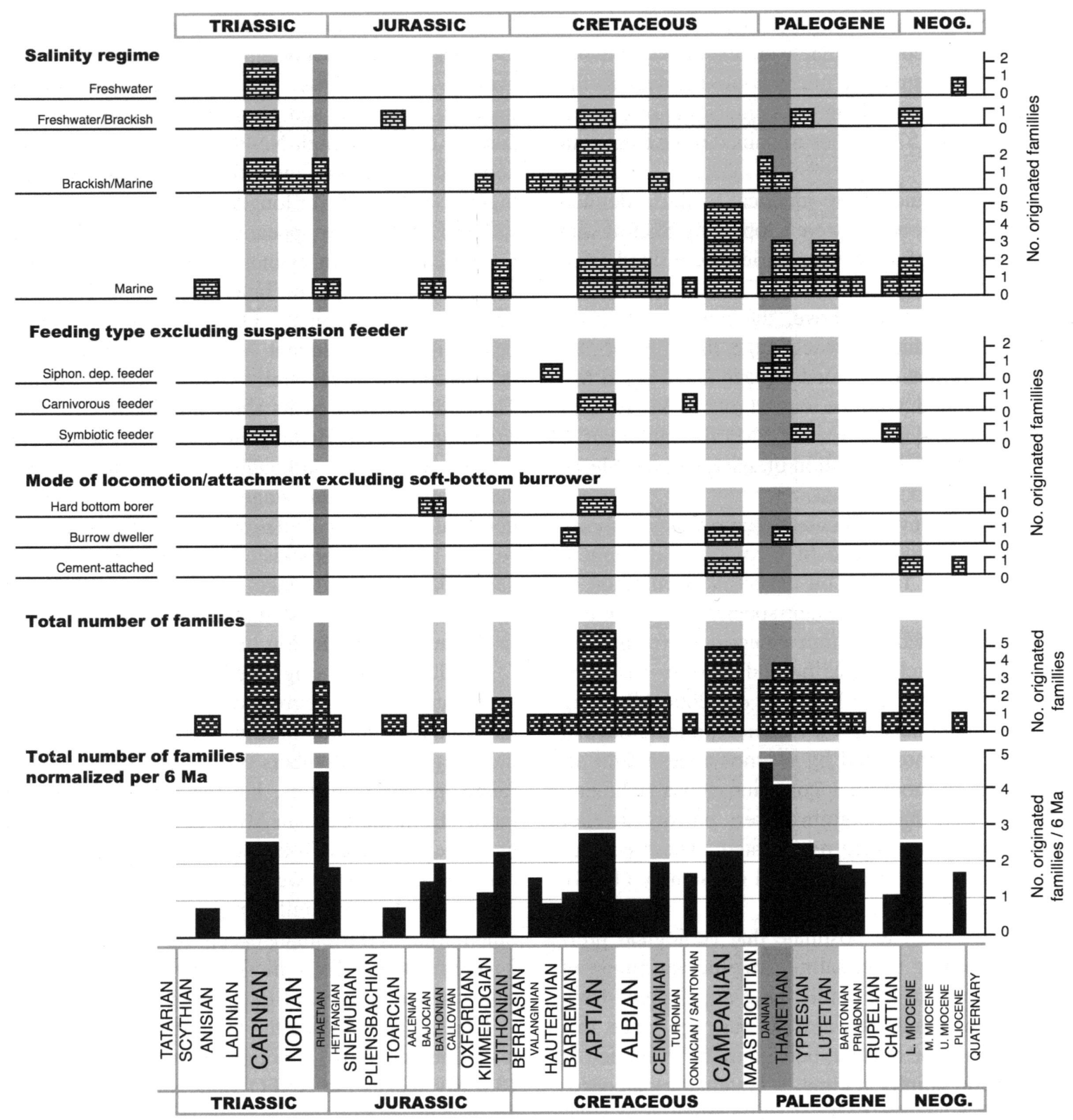

Figure 2. Temporal pattern of family origination in terms of salinity regime, feeding type, locomotion/attachment mode, as compared to total number of family originations and the same normalized for $6 \mathrm{Ma}$, in the Mesozoic and Cenozoic. Thick and weak shading as in Figure 1.

the second largest individual value, but the NNFO value is only moderately high due to the long interval involved of 13.0 My, as is the case for the Aptian and Albian. All the originated families were marine. The first origination of a cementattached family (Chamidae) in Heteroconchia is noted. Also, one of the rare families of burrow-dwellers (Solecurtidae) originated.

The most massive origination of heteroconch families started from the Danian and ended in the Priabonian, this being termed the Paleocene/Eocene Interval. The NNFO values are highest in the Danian, becoming smaller onwards. The total number of families originated in this interval is 16. Most of these are marine, but some brackish/marine and freshwater/brackish families originated, such as Psammobiidae and Dreissenidae. Deposit-feeding families using long siphons originated in this interval. The Paleocene is noted for the occurrence of siphonate deposit-feeders, Psammobiidae (Danian), Scrobiculariidae and Semelidae (Thanetian).

In the Lower Miocene Origination Event the origination of three families was recorded: one freshwater family (Lymnocardiidae) and two marine families (Cleidothaeridae and Cooperellidae). An origination of a freshwater family, along 
with Etheriidae in the Pliocene, is noteworthy. Origination of freshwater families is limited to the early part of the Mesozoic (Late Triassic) and the later part of the Cenozoic (Neogene Period).

\section{Discussion}

Post-Paleozoic bivalve diversification has been considered as a typical example of adaptive radiation, and has been interpreted as the consequence of siphon formation (Stanley, 1968). Most of the new siphonate taxa were eulamellibranch heterodonts or their derivatives and possessed crossed-lamellar shell structure, and they adapted to a variety of infaunal habitats, which had been inaccessible to Paleozoic bivalves and brachiopods.

Skelton et al. (1990) analyzed the stratigraphic range of post-Paleozoic bivalve families and the familial composition of the bivalve fauna at that time, and found that most of the bivalve groups diversified more or less proportionately, but the mostly byssally attached epifaunal Pteriomorphia declined, and siphonate infaunal groups diversified at the expense of nonsiphonate groups. This result supports the view of Stanley (1968).

On the other hand, Kondo (2001) and Kondo et al. (2001) pointed out that life habit diversification and habitat expansion played important roles in the post-Paleozoic diversification of bivalves, and major life habit groups shown by modern bivalves appeared in the Late Cretaceous. Bivalves in this time period colonized beaches and rocky shores which had been mostly inaccessible for earlier bivalves. The tendency of thickening of shell beds during the Cenozoic (Kidwell and Brenchley, 1994) indicates the colonization of nearshore habitats by bivalves.

In contrast to ecological features originating from physiological and functional requirements, habitat preferences may have easily changed; numerous bivalve groups have changed their habitat throughout their evolutionary history with patterns of onshore to offshore migration (cf. Jablonski et al., 1983) and, conversely, shallow-marine (inner shelf) to nearshore migration (Kondo, 1991; Kondo et al., 2001). However, most of the examples cited were pterimorphians that changed their habitat. Heteroconch families tend to retain their original habitat preferences.

In this study, we consider that origination of new families was a consequence of prevailing environmental characteristics, because the emergence of such a characteristic environment allowed members of the family to evolve and survive. The temporally uneven origination and ecological trends in origination may reflect significant environmental changes on Earth in the Mesozoic and Cenozoic.

The Carnian to Hettangian Origination Interval is probably a composite of multiple environmental and evolutionary events. The Carnian is known to be the time of the first ma- jor bivalve radiation after the end-Permian mass extinction. Therefore, the radiation was probably part of the recovery stage from the severe mass extinction. The origination of two freshwater families, Unionidae and Mutellidae, in this stage is noteworthy. The environmental and tectonic significance of these originations is uncertain, but the Unionida is inferred to have arisen sufficiently prior to the Late Triassic to allow the differentiation of two of the four families of the unionoideans (Hyriidae and Unionidae) in the American Southwest (Good, 1998).

In the Rhaetian and Hettangian near the Triassic/Jurassic boundary event, some euryhaline families originated, including Neomiodontidae, a typical brackish-water family in the Mesozoic. In this period, the partial pressure of carbon dioxide was high enough to cause a temporary undersaturation of seawater with respect to both aragonite and calcite, which is reflected by a worldwide interruption of carbonate sedimentation at the T-J boundary (Hautmann, 2004). Also, more or less lower salinity conditions were inferred for part of the epicontinental sea (Hallam and El Shaarawy, 1982; Allison and Wright, 2005). It is expectable that this situation was advantageous to euryhaline families, which normally flourish in brackish conditions.

In this connection, Megalodontoidea and Hippuritoidea (rudists) are the most conspicuous and notable Heteroconchia in the Mesozoic, although not analyzed in this paper because they are extinct. According to Hautmann (2006), megalodontoids having an aragonite shell became smaller and finally extinct in the Late Jurassic. At the same time, Hippuritoidea originated with an outer calcitic shell layer, and they flourished in the Late Cretaceous calcite-facilitating conditions in the oceans. Excluding Megalodontoidea and Hippuritoidea, such a seawater chemistry did not affect the evolutionary pathways of most of the Heteroconchia, probably because they are mostly infaunal and shell sizes were smaller.

The Mid-Cretaceous and Paleocene/Eocene Origination Intervals and the Campanian Origination Event represent part of the adaptive radiation of bivalves colonizing nearshore habitats, such as shoreface, foreshore, tidal flats and rocky shores. This is probably the evolutionary consequence of increased nutritional levels due both to diversification of diatoms and other plankton (COSOD II, 1987) and of land plants, although none of the details of the timing of these influences is known. Increased predation pressure may have played some role (Vermeij, 1977; Hayami, 1990; Oji et al., 2003), but timing of these events needs at least stage-level examination. Physical environmental settings, such as separation of continents as a result of the breakup of Pangaea, along with rising sea levels, facilitated divergence.

The Lower Miocene may be worth mentioning. Three families originated then and its NNFO value is 2.5. Origination of a brackish/freshwater family, Lymnocardiidae, is noted, along with freshwater Etheriidae, which originated in 
the Pliocene. Lymnocardiidae originated in the Paratethys sea where salinity was much reduced (Davis, 1975), under the collisional setting of Africa and Europe. This implies that collisional tectonics tend to produce brackish/freshwater bivalves.

At least part of the long-term pattern stated above appears to match the Wilson Cycle (Dewey and Spall, 1975) corresponding to continental aggregation and separation, and should represent the dominant environmental features at the time of origination. In brief, continental aggregation tends to produce brackish/freshwater faunas, and breakup of continents may cause evolution of marine faunas. The actual rather complicated patterns recognized in this study are probably a composite of several effects such as this long-term pattern associated with the Wilson Cycle, changes in seawater chemistry, and changes in nutrient levels and predation pressures.

Life habit diversification and habitat expansion (Kondo, 2001; Kondo et al., 2001) were achieved by mostly euryhaline families such as Mactridae, Donacidae and Mesodesmatidae in the Mid-Cretaceous Origination Interval, and by Psammobiidae, Semelidae and Scrobiculariidae in the Paleocene/Eocene Origination Interval. These families are the descendants of the euryhaline families that originated in the Carnian to Hettangian Origination Interval, such as Arcticidae, Corbiculidae and Neomiodontidae, although the details of the phylogenetic relationships remain unclear. In this sense, euryhalinity was a prerequisite for colonizing nearshore habitats in bivalves, as is pointed out by Kondo et al. (2006).

\section{Acknowledgments}

We thank Dr. Yoichi Ezaki for inviting us to the symposium "The biofacies of greenhouse earth in the Paleozoic and Mesozoic" held at Osaka City University at the 2007 Annual Meeting of the Palaeontological Society of Japan, and giving us the opportunity of writing this paper. This study was supported by Kakenhi (19540495; Grant-in-Aid for Scientific Research (C)) of the Ministry of Education, Culture, Sports, Science and Technology.

\section{References}

Allison, P. A. and Wright, V. P., 2005: Switching off the carbonate factory: Atidality, stratification and brackish wedges in epeiric seas. Sedimentary Geology, vol. 179, p. 175-184.

COSOD II, 1987: Report of the Second Scientific Conference on Scientific Ocean Drilling (COSOD II). Joint Oceanographic Institutions for Deep Earth Sampling (JOIDES), Washington, D.C.

Cox, L. R., 1960: Thoughts on the classification of the Bivalvia. Proceedings of the Malacological Society of London, vol. 34, p. 60-80.

Davis, A. M., 1975: Tertiary Faunas, Vol. II, 2nd ed., 447 p. George Allen \& Unwin, London
Dewey, J. F. and Spall, H., 1975: Pre-Mesozoic plate tectonics. Geology, vol 3, p. 422-424.

Fürsich, F. T., 1994: Palaeoecology and evolution of Mesozoic salinitycontrolled benthic macroinvertebrate associations. Lethaia, vol. 26, p. 327-346.

Giribet, G. and Wheeler, W., 2002: On bivalve phylogeny: a high-level analysis of the Bivalvia (Mollusca) based on combined morphology and DNA sequence data. Invertebrate Biology, vol. 121, p. 271-324.

Gradstein, J., Ogg, G. and Smith, A. G., 2004: A Geologic Time Scale 2004. Cambridge University Press, Cambridge.

Good, S. C., 1998: Freshwater bivalve fauna of the Late Triassic (CarnianNorian) Chinle, Dockum, and Dolores Formations of the southwest United States. In, Johnston, P. A. and Haggart, W. eds., Bivalves: An Eon of Evolution-Paleobiological Studies Honoring Norman D. Newell, p. 223-249. University of Calgary Press, Calgary.

Hallam, A. and El Shaarawy, Z., 1982: Salinity reduction of the end Triassic sea from the Alpine region into northwestern Europe. Lethaia, vol. 15 , p. 169-178.

Harland, W. B., Armstrong, R. K., Cox, A., Craig, L., Smith, A. and Smith D. G., 1990: A Geologic Time Scale 1989, 263 p. Cambridge University Press, Cambridge.

Hautmann, M., 2004: Effect of end-Triassic $\mathrm{CO}_{2}$ maximum on carbonate sedimentation and marine mass extinction. Facies, vol. 50, p. 257-261.

Hautmann, M., 2006: Shell mineralogical trends in epifaunal Mesozoic bivalves and their relationship to seawater chemistry. Facies, vol. 52, p. $417-433$.

Hayami, I., 1990: "Mesozoic Marine Revolution" and the evolution of bivalves. Kaseki (Fossils), no. 49, p. 23-31. (in Japanese)

Jablonski, D., Sepkoski, J. J. Jr., Bottjer, D. J. and Sheehan, P. M., 1983: Onshore-offshore patterns in the evolution of Phanerozoic shelf communities. Science, vol. 222, p. 1123-1125.

Kondo, Y., 2001: Bivalve life habits and the evolutionary change. In, Ikeya N. and Tanabe, K. eds., Science of Ancient Life 3, p. 149-168. Asakurashoten, Tokyo. (in Japanese)

Kondo, Y., Tajima, T., Funayama, N. and Endo, H., 2001: Diversification of life habit and habitat in the Cenozoic bivalves. Biological Science (Tokyo), no. 53, p.158-163. (in Japanese)

Kondo, Y., Kozai, T., Kikuchi, N. and Sugawara, K., 2006: Ecologic and taxonomic diversification in the Mesozoic brackish-water bivalve faunas in Japan, with emphasis on infaunalization of heterodonts. Gondwana Research, vol. 10, p. 316-327.

Oji, T., Ogaya, C. and Sato, T., 2003: Increase of shell-crushing predation recorded in fossil shell fragmentation. Paleobiology, vol. 29, p. 520526.

Sepkoski, J. J. Jr., 1981: A factor analytic description of the Phanerozoic marine fossil record. Paleobiology, vol. 7, p. 36-53.

Skelton, P. W., Crame, J. A., Morris, N. J. and Harper, E. M., 1990: Adaptive divergence and taxonomic radiation in post-Palaeozoic bivalves. $I n$, Taylor, P. D. and Larwood, G. P. eds., Major Evolutionary Radiations. Systematics Association Special Volume No. 42, p. 91-117. Clarendon Press, Oxford.

Skelton, P. W. and Benton, M. J., 1993: Mollusca: Rostroconchia, Scaphopoda and Bivalvia. In, Benton, M. J. ed., The Fossil Record 2, p. 237-263. Chapman \& Hall, London.

Stanley, S. M., 1968: Post-Paleozoic adaptive radiation of infaunal bivalve mollusks-a consequence of mantle fusion and siphon formation. Journal of Paleontology, vol. 42, p. 214-229.

Tokuyama, A., 1960: On the bio- and litho-facies of the Hirabara Formation in Prov. Nagato, West Japan. Japanese Journal of Geology and Geography, vol. 31, p. 23-38.

Vermeij, G. J., 1977: The Mesozoic marine revolution: evidence from snails, predators and grazers. Paleobiology, vol. 3, p. 245-258.

Yabe, H., Nagao, T. and Shimizu, S., 1926: Cretaceous Mollusca from the Sanchu-graben in the Kwanto Mountainland, Japan. Science Reports of the Tohoku Imperial University, Second Series (Geology), vol. 9, p. 3376. pls. $12-15$. 